Elsevier required licence: (C) $<2018>$. This manuscript version is made available under the CC-BY-NC-ND 4.0 license http://creativecommons.org/licenses/bync-nd/4.0/ 


\title{
Applying Institutional Theories to Managing Megaprojects
}

\begin{abstract}
This paper contributes to Rodney Turner's initiative to develop a theory of project management from practice. Organizational scholars studying strategy suggest that more attention needs to be paid to practices involved in organizing, as well as the institutional contexts in which these practices are embedded. Taking a cue from strategy-in-practice approaches, it is proposed that institutional theories can be used to address some questions that have not been answered adequately regarding megaprojects. Institutional theories also seem to be gaining the attention of scholars investigating large, global, infrastructure projects as reported in engineering, management and construction journals. Increasingly, it is evident that the problem areas attached to these projects stretch beyond technical issues: they must be considered as socio-technical endeavours embedded in complex institutional frames. The authors suggest that studying how to deal with institutional differences in the environment of megaprojects has both theoretical and practical implications.
\end{abstract}

Keywords: megaprojects; institutional theory; project management; project organizing; managing the socio-political context; project management research 


\section{Introduction}

This paper is a contribution to the Festschrift to mark Professor Rodney Turner's twenty-five years of contribution as Editor of the International Journal of Project Management. Under his watch, it has become a leading journal in the field. In considering his seminal work on 'Managing the project-based organization', we include a discussion of two of his major contributions to the project management literature — project-based management (Turner, 1999) and management of large projects and programmes (Turner, 2004). By linking megaprojects and institutional theory, we will add to his quest to develop a theory of project management. As readers of this journal may recall, Professor Turner published four editorials in 2006 raising a series of premises and dilemmas entailed in developing a theory of project management: questions were raised about the nature of project management (Turner, 2006a); the nature of project governance and project management (Turner, 2006b); the functions of project management (Turner, 2006c), and the nature of the functions of project management (2006d).

We start this paper by describing both megaprojects and institutional theory before addressing why we think institutional theory is useful in studying megaprojects, with a brief literature review. We then ask what particular aspects of institutional theory could be useful for research into megaprojects through a discussion on some key features of relevance to this paper. Next, we explain how institutional theory could be useful, with examples of institutional arrangements used in some megaprojects. We then focus on a few aspects of megaprojects worth investigating using an institutional theory lens, and propose a few research questions. Finally, we discuss how adopting methods used by institutional researchers could be beneficial to study megaprojects.

\section{Innovating theory in project management}

Rodney Turner (2006) has observed that the statement 'that there is not yet a theory of project management' is false; because in his own practitioner-oriented work an embryonic theory may be found. More explicitly, in an earlier paper by Turner with Müller (2003) a statement of what the premises of that theory might be is attempted, cast in fairly static and economistic terms: 'If the project 
is viewed as a temporary production function, for assigning resources to the implementation of change objectives, it delineates each project, and suggests why it should be of a certain size. Further it differentiates projects from programmes and portfolios of projects' (p. 7). Doubtless, there is some mileage in thinking of a project as a production function — but not a great deal. In economics, a production function relates physical output of a production process to physical inputs or factors of production. The absence of purchase of this definition should be evident: it is output oriented; the output is defined in physical terms, as are the inputs. In other words, the project is a classical 'black box'. Sauer and Reich (2007) respond to Rodney Turner's attempts to propose a theory of project management by stating that while normative research can produce a theory that could be valued by practitioners, it will be necessary to consider a number of theories that accurately 'reflects on what actually happens and what actually makes a difference' (p. 1).

Inputs and outputs hardly define projects, except in limited, functional terms. Beyond these, projects are defined by their social construction by those who sponsor, fund, make, contest and use them. Projects are also defined by the dreams and nightmares they enact, as well as the illusions and obdurate realities with which they come into conflict. Project processes and their institutionalization, their coming to be and passing away, and the institutional traces they build, remember, forget and sometimes leave behind - above all, it is these that define projects. Megaprojects should be seen as sites of conflicting institutional logics brought to bear on their processes as the social and material constructors attending to them bring their life worlds to bear on the processes undertaken and forgone. Logics are the "organizing principles which inform actors in a domain of activity how they are to behave" (van Gestel \& Hillebrand, 2011, p. 232). In recent approaches to strategy and organizations, there is widespread consensus that we need to pay more attention to the practices involved in organizing, and the institutional contexts in which these practices are embedded. Institutional theory is a valuable framework for thinking about organizing megaprojects. Projects in general and megaprojects in particular are engagements in which considerable institutional work is required for their accomplishment, often in ways that challenge some logics and predicates certain institutional work. 
The idea that projects should be seen in part in institutional terms is not entirely novel for the project management world: the idea that 'institutional management' should precede 'technical management' has been promoted by scholars writing about international and global infrastructure projects (Chi et al. 2014). Indeed, prominent project management scholars have advocated the importance of institutional factors in projects (Dille \& Söderlund, 2011; Engwall, 2003; Morris \& Geraldi, 2011; Miller \& Hobbs, 2005). Nowhere does the application of institutional theory to project management topics seem more relevant than in application to megaprojects.

Flyvbjerg (2014) defines megaprojects as 'large-scale, complex ventures that typically cost US\$1 billion or more, take many years to develop and build, involve multiple public and private stakeholders, are transformational, and impact millions of people' (p. 6). Using these criteria, some examples of recent megaprojects around the world include: high-speed rail lines (Chuo Shinkasen Maglev Line in Japan); airports (Singapore Changi Airports); seaports (Port of Hamburg in Germany); motorways (Lamu Port South Sudan Ethiopia Transport (LAPSSET) Corridor); National Broadband (National Broadband Network in Australia); major events (London Olympics); hospitals (Chris Hani Baragwanath Hospital in Johannesburg); large-scale signature architecture (Guggenheim Museum in Bilbao); wind farms (Gansu Wind Farm Project in China); offshore oil and gas extraction (Petrobras's Floating Production, Storage and Offloading Units in Brazil); new aircraft (Boeing Dreamliner); cruise ships (Royal Caribbean's Harmony of the Seas); container ports (Shanghai); scientific projects (Cyclotron particle accelerator); bridges (Øresund bridge connecting Sweden and Denmark); supply chain systems (Amazon, USA); and even large-scale public good projects (Swachh Bharat, India's Clean India program).

Applying success factors used in project management, megaprojects are often criticised for cost overruns (1400\% in the case of the Sydney Opera House), long delays (eight-year delay of the Boston Big Dig Central Artery and Tunnel) and not delivering the benefits they were expected to deliver (Millennium Dome in London). Nonetheless, many more megaprojects are being conceived and a smaller but still substantial number being built, resulting in the 'megaproject paradox' (Flyvbjerg et al., 
2003). Flyvbjerg (2014) suggests that the megaproject boom is created by four 'sublimes': technological (pushing the boundaries to build bigger, taller or faster); political (craving for visibility), economic (making money and creating jobs), and aesthetic (a love of creating iconic structures).

Ambition often runs ahead of accomplishment in megaprojects. According to Merrow (2011, p. 12), many such projects 'end up being disappointing to their sponsors; a fewer number turn out to be destroyers of shareholder wealth; and a few are horrendous with respect to anything and everything involved - the investing companies, the local population and the environment'. Gellert and Luynch (2003, p. 15) consider megaprojects as displacements causing creative destruction as 'they transform landscapes rapidly and radically, displacing mountaintops, rivers, flora and fauna, as well as humans and their communities'. They classify the displacement caused by megaprojects as social (e.g. planned eviction and resettlement; loss of access to resources) and bio-geophysical (e.g. deforestation; loss of wildlife populations) (p.16).

The criticisms are valid: bigness in ambition and scale of project does not necessarily produce spectacular achievement in terms of the myriad criteria of audit. For this lacuna, some responsibility must rest on the project management profession. So, what do project management practitioners and researchers need to know about the characteristics of megaprojects so that they can be managed and evaluated better? Do conventional project management methodologies and practices need remedy or extension? Do project managers and sponsors need to be trained to see that megaprojects need different approaches from those used to manage conventional projects? Yes, says Flyvbjerg (2017, p. 2), when he argues that 'Megaprojects are a completely different breed of project in terms of their level of aspiration, stakeholder involvement, lead times, complexity, and impact. Consequently, they are also a very different type of project to lead'.

By analysing the literature on megaprojects (Altshuler \& Luberoff, 2003; Flyvbjerg, 2017; Flyvbjerg, 2014; Flyvbjerg, Bruzelius \& Rothengatter, 2003; Greiman, 2013; Grün, 2004; Merrow, 2011; Miller \& Lessard, 2000; Morris, 1987; Oliomogbe \& Smith, 2012), we arrived at the following characteristics that could justify a different approach to manage them. 
Reach: Demand enormous human, financial and technological resources, and can have effects beyond national borders due to severe environmental impacts.

Duration: Time spans often extending beyond the political life cycle of a national government; and much longer life expectancy when benefits are also included in their completion and evaluation.

Cost: Often cost between 500 million to 1 billion US dollars; financing is complex with various arrangements, and may require large loans from international funding agencies that may impose restrictions on the ways in which the project is managed.

Risks and uncertainties: Often use untested technologies and processes, posing dangers to people in the project as well as communities affected by the project; require careful considerations in risk allocation; and could affect the careers and reputations of people involved.

Widely disparate actors: Often take a long time to materialize due to the enormity of good information required from political, economic and environmental aspects; and involve a wide variety of disparate actors who often have conflicting interests.

Arenas of controversy: Subjected to public and media scrutiny; success criteria are often fuzzy and misrepresented; power and politics affecting their evolution and management; face change of priorities or direction due to external agencies; and more and more of these are being built despite their poor reputation (creating the megaproject paradox).

Legal and regulatory issues: Legal claims and litigation; insurance issues, safety, security; conflicts resulting in extensive dispute-resolution activities; taxation effects over time; disruptions due to new regulations by government and statutory authorities; and face multiple governance regimes over the duration of the project. 
Value destruction: Social, economic and ecological destruction of value due to the size and cost of the labour force required, the requirements of securing and keeping scarce experts and specialized suppliers, accessing substantial sources of financial credit and enormous displacement issues, both socially and bio-geophysically, all destroying value.

It could be argued that some of these points may be relevant to any complex or large project. What differentiates megaprojects is their reach and the broad impact they could have on the society and environment — facing activist groups and hostile media opposed to the project, managing political pressures from key stakeholders and dealing effectively with public opinion. More intellectually, in terms of organization theory, we might say that what characterizes megaprojects is that to be accomplished, they must combine actors from fields governed by divergent logics and have them collaborate and make sense. Providers of capital and labour, contractors and subcontractors, regulators and protestors, ecologies and economies, communities and broader publics are all entangled in the institutional field, bringing to bear diverse institutional logics. These terms belong to the field of institutional theory, which we shall explore next.

\section{A Brief Introduction to Institutional Theory}

Institutional theory takes its cue from an open systems view that its environment affects an organization and that this environment is, in part, a social construction that is deeply historically sedimented (Clegg, 1981). Institutions, in this context, are the 'rules of the game' that govern social exchanges undertaken by individuals and organizations (North, 1990). According to Luhman and Cunliffe (2013, p. 85) 'the issue of [social] legitimacy — how organizations adapt to their environment and manage their credibility — is the concern of institutional theory'. Many contributors have expounded institutional theory, chief being, for pedagogic purposes, Scott and his co-authors (Levitt \& Scott, 2017). Scott (2014, p. 56) defines institutions as comprising 'regulative, normative and cultural-cognitive elements that together with associated activities and resources, provide stability and meaning to social life'. These are theorized as 'institutional pillars'. Regulative elements use explicit rules and surveillance activities; normative elements look at prescriptive as well as obligatory dimensions; and cultural-cognitive 
elements rely on shared beliefs (culture), and are dependent on individual cognition. Early conceptualizations of institutions and their impact described how institutional forces brought about conformity of behaviour in social settings. For instance, DiMaggio and Powell's (1983) seminal work proposed why coercive, normative and mimetic forces pressure organizations within a field to take on similar forms to survive competitively in their environment - a phenomenon termed isomorphism. While these forms may or may not be optimal from a productivity or output perspective, they are perceived as legitimate and hence essential. Early institutional work thus emphasized the role of institutions in bringing about conformity, and highlighted the notion of how non-conformance to institutions could incur heavy penalties in the form of legal as well as social sanctions (Meyer \& Rowan, 1977; Jepperson, 1991). Coupled with notions of institutional 'persistence' (Zucker, 1977), these perspectives led to a static conceptualization of institutions as immutable forces that reinforced and regulated behaviours and social order.

While traditional views of institutional theory suggested a constrained view of an organization influenced by the environment, more contemporary work on institutions has deviated from this theme; more recent scholars have both observed and attempted to explain change in social settings. Scott (2008) posits that institutional systems do change due to both exogenous and endogenous factors. Changes from within can occur when dissonance is detected between macro factors imposed by the external environment that affect the practice of micro activities performed in local situations. Oliver (1991, p. 175) suggests that 'organizations do not invariably conform to the rules, myths or expectations of their institutional environment' but use various ways to resist institutional pressures through strategic responses such as avoidance, defiance or manipulation. Given that the order in a social setting, or the 'rules of the game', are constantly changing, scholars now conceptualize organizations or fields as cohabited by a variety of institutional logics that are constantly jockeying for pole position (Fligstein \& McAdam, 2011; Friedland \& Alford, 1991; Seo \& Creed, 2002). There is recent literature on organizational responses to settings of institutional complexity (Vermeulen, Zietsma, Greenwood \& Langley, 2016). Complexity can occur when there are multiple dominant or co-existing logics (Fincham \& Forbes, 2016), or where there are interstitial spaces in which logics overlap (Fan \& Zietsma, 2016). 
In this view, social settings are arenas in which there is potential for either institutional conflict or concordance, in which social order is forged and remade as various logics gain primacy over time, and enrol and translate other logics to shared sensemaking. In certain cases, the resultant rules of the game will be hybrid configurations or bricolages of competing institutional forces (Douglas, 1986).

The outcome of these institutional struggles for order is often determined by 'Institutional Entrepreneurs' (Fligstein, 1997). Paul DiMaggio, in a 1988 paper, published in Lynn Zucker's Institutional Patterns and Culture, describes institutional entrepreneurship as the activity underlying the creation of new institutions.

$[\mathrm{N}] \mathrm{ew}$ institutions arise when organized actors with sufficient resources see in them an opportunity to realize interests that they value highly [Institutional entrepreneurs] create a whole new system of meaning that ties the functioning of disparate sets of institutions together (DiMaggio, 1988, p. 14).

Scott (2014, p. 95) explains that institutional entrepreneurs are 'actors who are able to mobilize resources to realize interests they value'. Institutional entrepreneurs change the game, introduce new games, or transform the rules of institutionalized games and can be individual or collective agents. A broad view of entrepreneurship focuses not only on the creation of new business organizations, but also on the generation of new organizational models and policies that change the direction and flow of organizational activity. Common to these diverse activities and domains is the recognition of opportunities. Without institutional entrepreneurs, and their vision and persistence, megaprojects would not be born. We not only have to focus on how individuals and groups attempt to shape the institutional context in a fashion that privileges their preferred policies and programs, but also the ways in which the wider environment both defines and creates opportunities for such entrepreneurship.

Lawrence and Suddaby (2013) argue that DiMaggio's (1988) concept of institutional entrepreneurship includes the influence of strategy and power, bringing actors and agency into the equation to create new institutions or remake existing ones. They hold that the focus of research in institutional 
entrepreneurship has been 'to elaborate the characteristics of, and the conditions that produce, institutional entrepreneurs. Somewhat less evident in these accounts however are detailed descriptions of what institutional entrepreneurs do' (p. 220).

We next look at how Institutions, Institutional Conflicts and Institutional Entrepreneurs can be useful lenses for viewing megaprojects, and how megaprojects research and institutional theory can mutually fill research gaps that exist in both fields.

\section{Why is institutional theory a useful lens to view megaprojects with?}

In a recent book published about project society, which focuses on institutional challenges of temporary organizations, Lundin et al. (2015) urge that neo-institutional theory needs to be applied to temporary organizations, such as projects. Based on the work of Scott (2003) and Gidden's (1984) concept of structuration and the relationship between agency and structure, they argue that "neo-institutionalism is better prepared than ever to inform research on projects and other forms of temporary organization' ( $\mathrm{p}$. 228). Lundin et al. (2015) suggest that project research should also consider the paradox of 'embedded agency': the embeddedness of agents in perceived institutional contexts that they must learn to change, organize and manage. These agents must be capable of influencing the context in which projects are carried out rather than their agency being determined by these contexts, whether prospectively in terms of adhering to plans that prove inflexible or reactively in terms of responding to exigencies and contingencies as they arise as unforeseen events. Considering these questions leads to consideration and investigation of the tensions between institutional determinism and agency, especially the role of project managers as 'entrepreneurs who leverage resources to transform existing institutions' (Battilana et al., 2009, p. 68).

One of the seminal papers urging project management scholars to consider institutional factors when investigating project management is by Morris and Geraldi (2011), who advocate thinking in the future about project management at three levels: 1) Technical, 2) Strategic, and 3) Institutional. They define the institutional level as 'creating the context and support for projects to flourish and for their 
management to prosper' (p. 20); in other words, creating, organizing and managing a complex institutional field. They build upon work critiquing the treatment of projects in isolation by Engwall (2003) and Söderlund (2004). In order to avoid doing this, Morris and Geraldi (2011) considered the institutional level as an emerging area of research in project management. While the first two levels proposed by Morris and Geraldi (2011) are concerned with what happens within the project, the third level includes consideration of the broader environment in which the project is situated, with the authors arguing that paying attention to this level can contribute to project success and long-term performance, both often mentioned as failings of megaprojects (Flyvbjerg, 2014).

Some of the areas that Morris and Geraldi (2011) include in analyzing a project at the institutional level, that are of particular importance in megaprojects, are sponsorship and governance, which includes governmentality (Clegg et al. 2002; Müller, 2016); project structure and context to deal with the interplay between structure and agency (Sydow, Lindkvist \& DeFillipi, 2004); strategic resourcing and procurement, such as relationship-based contracting (Bresnen \& Marshall, 2002); integration with external groups (Scott, Levitt \& Orr, 2008) and attention to the societal level (Lundin et al., 2015). The latter is particularly demanding as the pressure for more megaprojects increases due to factors such as population growth, responding to increasing needs for infrastructure and energy, concerns over carbon emissions resulting in refurbishment projects, sustainability problems arising with water and waste in both rich and poor countries as a result of prior industrialization projects.

While project management journals have only recently started publishing empirical work on projects and institutions, it appears that construction and engineering management journals have taken a lead in this area. Miller and Lessard (2000), who carried out the IMEC's research program from Canada on 60 large engineering projects (LEP), state clearly that 'the presence of coherent and well-developed institutional arrangements is, without doubt, the most important determinant of project performance' (p. 23). They further argue that institutional issues play a part throughout the lifecycle of LEPs. 'Project configurations need to be adjusted many times to meet the shifting expectations of [institutional actors such as] bankers, regional groups and clients' (p. 44). They also found that 'projects are shaped in 
episodes', and 'each episode opens new options and closes old ones until sponsors and partners achieve final lock-in' (p. 102.). To the list of sponsors and partners, we would want to add the importance of resistors and all those who sense value is being destroyed by the project.

Mahalingam and Levitt (2007) show that institutionalized views often differ and come into conflict in megaprojects, that these differences straddle regulative, normative and cognitive dimensions (Jia et al. 2011) and that resolving regulative conflicts is progressively easier than normative ones, with cognitive conflicts being the most difficult to resolve. From a study carried out on institutional project arrangements in high speed rail projects in China and Taiwan, Chi and Javernick-Will (2011) list aspects of institutional pillars that have been found to be problematic in rail projects: 'Strict regulatory, legitimacy and normative requirements constrain projects but often, these can be negotiated. Normative and cultural institutions, on the other hand, are long lasting and cannot be changed easily over a shortterm project' (p. 609).

Project management relies on normative isomorphism through instilling professional standards as its major regulatory device, but these invariably lag both field-based learning — as do tendencies to isomorphism premised on both the state's coercive institutional requirements, expressed though regulation and law - as well as the mimetic isomorphism that comes from the experience of being a project manager. For the latter, to the extent that the experience has not been gained in the megaproject field, the forms of mimetic isomorphism available will be largely irrelevant, being embedded in far more prescriptive and less challenging contexts; in which planning frames conventional project management with little regard for how overlapping, contradictory or competing institutional logics can disrupt preferred models of isomorphism, and with little or no experience or training in how to try and make distinct logics collaboratively cooperative. Javernick-Will and Scott (2011) add that while the three pillars framework is an analytical distinction, in reality, these elements overlap and affect each other. That which has been learnt mimetically struggles with that which is imposed regulatively, while that which is normatively induced through professional standards will struggle to organize and manage novel situations and contexts whose eventfulness ensures that they have not previously been accounted. 
They state that while most of the international project management literature focuses on the regulative elements, it is the normative and cognitive-cultural factors that have received less attention, perhaps because project management research has often tended to look at projects primarily through the lens of economics. It may also be difficult for project management researchers, with a training more in the applied engineering rather than social sciences, to study normative and cultural-cognitive factors: they are rarely exposed to the ideas and training in the methods used by sociologists and historicalinstitutionalists (to examine normative factors) and anthropologists, cross-cultural psychologists, ethnomethodologists and organization scholars (to examine cultural-cognitive factors).

Javernick-Will and Scott (2011, p. 258) provide a list of important types of institutional knowledge required on international projects that is relevant to our further discussions in this paper, summarised in Table 1. 
Table 1 - Important Types of Institutional Knowledge (Adapted from Javernick-Will \& Scott 2011, p. 258)

\begin{tabular}{|l|l|l|}
\hline Regulative & Normative & Cultural-Cognitive \\
\hline Laws and Regulations & Work Practices & Local Cultural Beliefs \\
\hline Operating Laws & Social Norms, Expectations \& & Language/Concepts/Meanings \\
\hline Knowledge of Government & Industry Organization & \\
\hline Design \& Construction & Logistics & \\
\hline Approval Processes & Relationships & \\
\hline & Resources \& Productivity & \\
\hline & Market Knowledge & \\
\hline
\end{tabular}

Javernick-Will \& Scott's (2011, p. 272) study of fifteen international firms in the Architecture, Engineering and Construction (AEC) industries reveals 'normative knowledge, a largely understudied area, as the most frequently mentioned type of knowledge participants regarded as important for firms to acquire' (p. 273). By normative knowledge, they mean the professional practice that needs to be improvised in use rather than applied from a prior template. While normative knowledge is particularly important in international projects, regulative and cultural-cognitive elements are also important considerations for setting up a megaproject in the infrastructure sector. The three pillars are thus interrelated and, Scott (2011, p. 57) proposes, 'the most basic mechanisms of the cultural-cognitive pillar provide the foundation on which regulative and normative forces operate'.

Levitt and Scott (2017) concur with project management scholars that projects go through shaping phases or episodes (Miller \& Lessard, 2000; Smith \&Winter, 2010), and 'the shaping phase is arguably the most critical phase of a project and the most turbulent in terms of the institutional field' (p. 17). Even though institutional theory might on the surface appear to be more useful for dealing with the difficulties associated with the front-end of a project, it is also applicable to the later stages of a project, 
when a project is executed (Williams \& Samset, 2010). Scholars in these traditions have therefore made a case for the need for an institutional perspective in megaprojects research and the relevance of institutions in the context of megaprojects. Furthermore, the kinds of institutions and institutional conflicts that become manifest in megaprojects have also been enumerated through empirical research. Despite this knowledge on 'what' institutions impact megaprojects, we know very little of 'how' institutional forces manifest, act and are resolved on megaprojects. The dynamics of institutional forces on megaprojects is thus a gap in our understanding of institutions and megaprojects, and can best be understood through the lens of institutional or organizational fields.

\section{Crafting a Research Agenda for an Institutional Analysis of Megaprojects: Gaps and the way}

\section{forward}

The institutional context is usually referred to as the institutional 'field' (Wooten \& Hoffman, 2016). The institutional field may be defined in relational terms as 'those organizations that, in the aggregate, constitute a recognized area of institutional life: key suppliers, resource and product customers, regulatory agencies, and other organizations that produce similar services or products' (DiMaggio \& Powell, 1983, p. 148). Levitt and Scott (2017, p. 8) propose that (global) megaprojects can be viewed in field terms, following DiMaggio and Powell's (1983) definition of a field as a recognized area of institutional life. Hoffman (2001) has extended this concept by adding that 'fields should be seen as contested centres of debate where competing interests negotiate the interpretation of what they constitute as key issues' (Powell \& Colyvas, 2008, p. 2).

Megaprojects, by definition, are heterogeneous conglomerations of specialized actors drawn from a variety of backgrounds and contexts, in response to the specific technical and managerial requirements of the project. Given the disparate logics that different stakeholder groups will consequently bring to the table, the organizational field of a megaproject will be subject to institutional contestations. Following Suddaby (2010, p. 18), who suggests that institutional researchers 'have to conduct research at the organizational level of analysis and view organizations as interpretive mechanisms that filter, decode and translate the semiotics of broader systems' (p. 18), project management researchers should 
also focus on investigating megaprojects from an internal perspective, paying attention to how organizational actors create changes in the institutional context.

Clearly, the institutional field for a megaproject is more wide-ranging and complex than for a major project, in which reach, duration, costs, risks and uncertainties, widely disparate actors, arenas of controversy, legal and regulatory issues, and social, economic and ecological destruction are more predictable. The essence of the megaproject, and the reason that so many fail to be on time, within budget or to deliver to specifications, is the considerable amount of institutional entrepreneurship that they require. Widely disparate actors, each with their own resources that are critical to the project, bring with them a set of prevailing logics that each feel are uniquely applicable to megaproject situations. Polycentric governance structures obfuscate hierarchical decision making on megaprojects. As a result, institutional clashes or contradictions continually result, which often need to be resolved through the creation of a 'new order'. An example of such a conflict is reported by Mahalingam, Levitt and Scott (2011) from an investigation of Indian metro rail projects They observed conflicts arising out of disputes between local public officials charged with overseeing the rail projects, who adopted a 'rules orientation', and design and construction engineers from overseas working on these projects, who adopted a 'results orientation'. Benefits are overstated, risks minimized, forecasts optimistic, predictable stakeholder grievances minimized, value destruction hardly countenanced (Flyvbjerg et al., 2003). Institutional entrepreneurs are therefore critical to crafting a 'new order' from a necessary set of logics to coordinate work across entities on megaprojects, but whose temporality may not last beyond the duration of the project.

A review of the literature demonstrates that megaproject managers and leaders are often required to assist in the development phases of a megaproject, extending their role and responsibilities beyond what is expected of them in conventional projects (Ashokan, 2013). These projects also seem to require stronger project ownership or sponsorship to deal with the power and political issues that have an impact on them due to the various institutions that have a stake in such projects (Brady \& Davies, 2014; Gil \& Lundrigan, 2012). Therefore, preparing to meet institutional demands that may be placed on 
megaprojects is essential for not only successful project management practitioners, but also those who research them.

Accepting that there may well be diverse institutional logics at work in any polyarchic multiorganizational and multi-institutional project, project managers will have to navigate institutional plurality and complexity. While plurality and complexity are often taken to be synonymous, institutional plurality is a structural condition of a field or relational space where multiple logics exists (Kraatz \& Block, 2008). Institutional complexity, by contrast, is the experience of actors of 'logic contradictions by organizations' (Micoletta, Lounsbury \& Greenwood, 2017; Greenwood, Raynard, Kodeih, Micelotta, \& Lounsbury, 2011). Having 'logic contradictions' does not necessarily entail megaproject institutional failure. Several examples of how megaprojects have used novel institutional arrangements to improve outcomes can be found in the project management literature. Table 2 lists the points in a project at which such strategies have been implemented, in order to try and produce less contradictory logics in action.

Table 2: Examples of institutional arrangements adopted in megaprojects

\begin{tabular}{|c|c|c|c|}
\hline When & Location & Project & Arrangements/Strategies \\
\hline Throughout & USA & $\begin{array}{l}\text { Boston Big Dig } \\
\text { (Central } \\
\text { Artery/Tunnel) }\end{array}$ & $\begin{array}{l}\text { Setting up the Oversight Coordination } \\
\text { Commission with representatives from Offices } \\
\text { of the Attorney General, State Auditor and } \\
\text { Inspector General to protect the public interest, } \\
\text { ensuring cost savings in an integrated way, and } \\
\text { reducing red tape. (Greiman, } 2013 \text {, p. } 368-374 \text { ) }\end{array}$ \\
\hline Start & UK & $\begin{array}{l}\text { Heathrow Terminal } \\
\text { T5 }\end{array}$ & $\begin{array}{l}\text { T5 handbook to define how BAA would work, } \\
\text { carrying the risk and rewarding success, but not } \\
\text { penalizing failure (Brady \& Davies, 2014) }\end{array}$ \\
\hline
\end{tabular}




\begin{tabular}{|c|c|c|c|}
\hline Start & UK & $\begin{array}{l}\text { Heathrow Terminal } \\
5\end{array}$ & $\begin{array}{l}\text { T5 agreement a cost-plus contract that } \\
\text { established collaborative rules for integrated } \\
\text { project team working (Brady \& Davies, 2014) }\end{array}$ \\
\hline Start & UK & London Olympics & $\begin{array}{l}\text { Setting up two bodies, the Olympic Delivery } \\
\text { Authority and a joint venture between } \\
\text { contractors, to create a delivery partner to } \\
\text { deliver venues and facilities (Brady \& Davies, } \\
\text { 2014) }\end{array}$ \\
\hline During & UK & $\begin{array}{l}\text { London's Cross } \\
\text { Rail }\end{array}$ & $\begin{array}{l}\text { Pursuing program and project partners to form } \\
\text { a collocated Integrated Project Team (Davies, } \\
\text { MacAulay, DeBarro \& Thurston, 2014) }\end{array}$ \\
\hline During & UK & $\begin{array}{l}\text { London's Cross } \\
\text { Rail }\end{array}$ & $\begin{array}{l}\text { Innovation Program Manager and Coordinators } \\
\text { to drive the innovation strategy (Davies, } \\
\text { MacAulay, DeBarro \& Thurston, 2014) }\end{array}$ \\
\hline Start & India & $\begin{array}{l}\text { Konkan Rail } \\
\text { Project }\end{array}$ & $\begin{array}{l}\text { Direct contact with land owners, bypassing the } \\
\text { state government, and reaching agreement to } \\
\text { clear the land (Ashokan, 2015) }\end{array}$ \\
\hline During & India & $\begin{array}{l}\text { Konkan Rail and } \\
\text { Delhi Metro }\end{array}$ & $\begin{array}{l}\text { Paying contractors } 80 \% \text { of the invoice based on } \\
\text { their measurement to alleviate cash flow issues } \\
\text { and focusing them on their work (Ashokan, } \\
\text { 2015) }\end{array}$ \\
\hline
\end{tabular}

From Table 2 we can see that megaproject managers and sponsors have started using innovative institutional arrangements to improve the outcomes from megaprojects in several projects across the world. These strategies have been used both to set up a project as well as to give it shape. Strategies found in the literature focus more on regulative and normative issues and it was not easy to find examples of strategies focusing on cultural/cognitive issues. One exception that charts how cultural and 
cognitive issues gave rise to contradictory logics is the study of the Panama Canal Megaproject (van Marrewijk, Ybema, Smits, Clegg \& Pitsis, 2016), which was riven by such conflicts.

In the context of Indian megaprojects, for instance, the change of safety culture is a case in point. As Mahalingam and Levitt (2007b) point out, safety was traditionally neglected on Indian construction sites until the advent of megaprojects such as the Delhi Metro, where international contractors called in to undertake specialized tunnelling operations attempted to change cognitive beliefs relating to the value of safety in project work. Through a judicious mixture of regulations (incentives and penalties) and norms (safety awards, visibility from the Project Director, etc.), the safety culture on the project improved visibly. However, as can be seen from this discussion, most of the literature on institutional effects on projects makes a case for acknowledging these effects and tries to enumerate the arenas where institutional arrangements arise and affect megaprojects. The research gap that we proposed earlier on the dynamics of how megaprojects deal with institutional influences or, in other words, the story of how arrangements such as those mentioned in Table 2 came to be their relative permanence and ongoing enactment - remains unanswered.

While extant literature in the field of construction and engineering management has highlighted the connection between institutions and projects, and has also attempted to highlight the kinds of institutions that may differ and which among these may be salient differences, the dynamics of institutional work on megaprojects - be it institutional conflict resolution, institutional entrepreneurship or the creation of new/proto-institutional forms - have not received adequate attention. Based on Javernick-Will and Scott (2011) and Scott (2014), we identify the following questions for project management researchers, questions that do not seem to have been addressed adequately in the existing literature:

1. How do megaproject participants take into account social norms, cultural beliefs, local expectations and preferences to shape the megaproject structure and processes?

2. How are norms and work practices set and formed on megaprojects? 
3. How do megaproject managers weave their way through institutional contradictions and logics that lead to inter-institutional conflicts that affect their project?

4. What characterizes institutional entrepreneurs on megaprojects, what strategies do they enact and how successfully do they do so?

5. How do institutional dynamics influence outcomes on megaprojects?

\section{How can we carry out research in megaprojects applying institutional theory?}

While conventional research methods in project management research could be useful in investigating the regulative aspect of a megaproject environment, project management researchers may have to learn new methods used by institutional theorists in conducting their research (Drouin et al., 2013). Institutional theorists use several conventional methods commonly used by project management researchers such as surveys, case studies, interviews, ethnographic methods and participant observation.

Project management researchers are encouraged to consider using novel methods when applying institutional theory to megaprojects. Javernick-Will and Scott (2011) state that normative and culturalcognitive factors are often investigated using methods that sociologists and historical-institutionalists use (to examine normative factors) as well as by anthropological inquiry, cross-cultural psychology, ethnomethodology and organization studies (to examine cultural-cognitive factors). In this section, we will illustrate the use of discourse analysis as one of the novel approaches to conduct research about megaprojects.

\section{Discourse analysis}

Projects are, literally, projections. As such, a complex web of semiotics presents them in signs inscribed in detailed blueprints, consultancy reports, documented accounts, meetings, media and other forms of text. Texts are objects of discourse, discursively produced in and through languages — semiotic systems — such as images, drawings, models and, perhaps most importantly, the words of language. 
In the broadest terms, language defines the possibilities of meaningful existence at the same time as it limits them. Through language, our sense of ourselves as distinct subjectivities is constituted. Subjectivity is constituted through a myriad of what post-structuralists term 'discursive practices': practices of talk, text, writing, cognition, argumentation, and representation generally. (Clegg, 1989, p. 151)

Our social world is formed around discourse. Discourse shapes our understanding of social structures, such as organizations. As such, discourse is not about organizations; discourse itself is a form of organization and, therefore, organizational analysis is intrinsically discourse analysis. Discourse analysis is of vital importance when making sense of organizations, as it 'recognizes that the modern world we live in and the social artefacts we rely upon to successfully negotiate our way through life, are always already institutionalized effects of primary organizational impulses' (Chia, 2000, p. 513). An organization must not be thought of as a pre-existing entity, but as something that is constructed by pre-existing 'agents' through the use of words, gestures and symbols. Hence, language, and the way in which we use language and other forms of representation, is increasingly being recognised as one of the most important phenomena in the social sciences, as well as in management and organizational studies, and therefore as the foundation for empirical investigations of organizational issues. In other words, researching organizations or megaprojects empirically must entail addressing language itself, of how people use language, or how language uses people, the complexities of which do much to create everyday organizational life in its accomplishment (Chia, 2000).

There is a wide array of ways for using the term 'discourse' in social science and organization studies, and it is at times difficult to make sense of what people mean by it. Nevertheless, discourse has been widely accepted 'as a structuring principle of society, in social institutions, modes of thought and individual subjectivity' (Weedon, 2006, p. 364). This 'structuring principle' determines meaning and subjectivity: 'subjectivity is itself an effect of discourse' (Weedon, 1987, p. 86). Megaprojects are invariably arenas for the display of differently organized subjectivities: politicians as sponsors; bankers 
as creditors; communities as resistance; employees as managers and workers; ecologists as defenders of the environment, and so on.

Alvesson and Karreman (2000) propose two major and quite different approaches to discourse in organization studies: the study of the social text, which includes talk and written text in its social action contexts; and the study of social reality as discursively constructed and maintained, which is characterized by the shaping of situational social reality through language. The former may be inscribed in manifestos, prospectuses, vision statements designed to be public documents, tapping into formal rhetoric and recognized tropes; while the latter are much more contextual, indexing specific situations and understandings of them, often inscribed reflexively in the situational context. The primary distinction between these two approaches comes down essentially to the specificity of analyzed discourse. That is, whether organizational discourse analysis transcends the specific organizational micro-discourse and focuses on the situatedness of language used in a particular formal context beyond the texts of everyday situations (Discourse with capital D). Put simply, the first approach emphasizes the 'talked' and 'textual' nature of everyday interaction in organization, whereas the second is concerned with the determination of "social reality through historically situated discursive moves (Alvesson \& Karreman, 2000, p. 1126). What does that mean for megaproject management researchers?

When using institutional theory to make sense of megaprojects, discourse analysis can be used to make sense of the 'linguistic and symbolic life of organizations' to enable researchers to understand how practices 'create new objects with social controls that institutionalize them' (Lawrence \& Suddaby, 2013, p. 239). Three forms of discourses can be investigated using discourse analysis: rhetoric, narrative and dialogue. Rhetoric can be useful to analyse how symbols are used to change attitudes and beliefs, values and resulting actions. For example, Elattuvalapil Sreedharan, who led the Konkan Railway and Delhi Metro projects in India, used 'reverse clocks' that ran backwards and 'were brought in as part of a conscious decision to get the construction works done according to a predetermined schedule' (Ashokan, 2013, p. 139). They were installed in all offices and sites to instil a consciousness about time among all who worked on the project. Narratives (Boje, 2001; Czarniawska, 2004) can help to 
investigate how actors 'are able to create, communicate and embed stories that support the creating, maintaining and disrupting of institutions' (Lawrence \& Suddaby, 2013, p. 241). Dialogues are used in a group context and generative dialogue 'is a powerful form of institutional work, creating mechanisms of social control' (ibid, p. 241), and examine sets of interactions.

The 'procedural aspects of member's [of an organization] situated practices' (ten Have 2004, p. 27) is the context for the more situational analysis of discourse. In particular, research at this level attends to everyday talk as a phenomenon that skilled actors are able to bring off as practical accomplishments using more or less tacit rules of play. According to ten Have (2004, p. 32-34), four strategies can be adopted to collect data using ethnomethodology: close study of sensemaking activities in context; researchers putting themselves in the role of the member and examining their own sensemaking activities in context; closely observing situations in their natural settings and discussing their practical accomplishment with experienced practitioners, as well as audio or video recording of some of the products that are generated by ordinary practices, paying particular attention to the members' uses of categorization devices with which they make sense of the scenes they confront and constitute. More microscopically, researchers can study the categories in use in contexts in which diverse logics are demonstrated by the different categorizations (e.g. Baunsgaard \& Clegg, 2013). Organizational scholars who have investigated projects have used such methods (Clegg et al., 2002; van Marrewijk et al., 2016) as well as anthropological approaches (Löfgren, 2015). In earlier work, Clegg (1975) pioneered an approach to the rationalities exhibited in and underlining the diverse language games entered into by different stakeholders in project management. While this work was restricted to the site and project meetings, it could readily be extended to the constitution of the whole institutional field of megaprojects.

While institutionalists see 'institutions as rules that structure behaviour' (Steinmo, 2008, p. 126), differences exist between different schools of institutional theory. Institutionalists who belong to the rational choice school see human beings as rational individuals who weigh costs and benefits in the choices that they make, while sociological institutionalists see human beings as essentially socially constructed and constructing. Historical institutionalists, on the other hand, are interested in why a 
certain choice was made or why a certain outcome occurred, in terms of its historical framing and prefiguring. They do not believe that human beings are simple rule followers or strategic actors who use rules to maximize their returns. They are interested in explanation, not prediction, in extrapolating and understanding the members' specific experience of reality.

All projects are microcosms of cultures brought to bear on them by the various experiences of the project members in the many prior projects that they were involved in. Not only is there a multiplicity of experiencers with a multiplicity of experiences; there are also the unique contexts of the emergent cultures of the present project and its typifications in terms of all the prior projects experienced. According to Pickering (2008, p. 5) 'experience has always been a key term in cultural studies'. Cultural scholars are interested in studying 'how people make sense of their experience and interpret the social world' (ibid, p. 6). Any project is the repository of a multiplicity of stories and narratives. Narratives, with beginnings, middles and ends, as well as the more fragmentary stories that are heard, circulate and contested, constitute an important source of data collection (Boje, 2001; Czarniawska, 2004) in cultural studies. Cultural scholars use conventional methods such as interviews and focus groups but also use discourse analysis of spoken and written data and visual methods using images and video. van Marrewijk (2015) describes some examples using cultural studies in megaprojects.

\section{Conclusions}

We conclude that megaprojects may face certain challenges that differentiate them from normal projects, requiring different ways of organizing and managing. Institutional factors must be managed carefully in megaprojects because of the complexity of their institutional fields, the multiplicity of their logics and, on occasion, the duplicity of their entrepreneurs. While some project management scholars have urged researchers to use institutional theory in investigating projects, the take up is so far slight. However, researchers in the fields of engineering, management, construction and organization studies have been more forthcoming. While papers in project management journals may describe how megaprojects have used institutional arrangements, they have not investigated them using an 
institutional theory lens and have not dealt with the dynamics of dealing with institutional influences, which constitute a key part of project life.

In this article, we identified a few major questions that could be addressed by project management scholars to investigate megaprojects from an institutional theory lens that could be beneficial to project management theory and practice. We also illustrated the use of discourse analysis as a useful method for expanding project management scholarship when using an institutional theory lens. We invite researchers to apply novel methods used by researchers applying institutional theory to fill the research gaps identified in this article. First-hand empirical accounts of projects are likely to be invaluable in this endeavour. However, there is also much that can be gleaned from secondary analysis and expert testimony. For instance, two of the authors of this paper are in the process of organizing a round table to discuss challenges on megaprojects in India. As a part of this process, dialogues have been initiated with key megaproject actors (sponsors, project directors, financiers) in the Indian environment. Discursive analysis of these interactions shows that a multitude of logics are apparent in the shaping, procurement, execution and monitoring stages of projects. Land use regulations, for instance, conflict with project plans. Power plays between planners, politicians and project managers determine the outcome of these institutional conflicts - to what extent will existing land use rules be modified to accommodate plans for developing an infrastructure project, for instance?

Understanding the institutional framing, underpinnings and logics of megaprojects can provide the key to successful delivery of solutions in water, transportation, energy, communications, health, education and a variety of related sectors, through the development of best practices for building social, organizational and political legitimacy that can enhance the security and stability of the role that such projects play in an increasingly interconnected world. 


\section{References}

Altshuler, A. \& Luberoff, D. (2003). Mega-projects: The changing politics of urban public investment, Washington: Brookings Institution.

Alvesson, M. and Karreman, D., (2000). Varieties of discourse: On the study of organizations through discourse analysis. Human Relations, 53(9), 1125-1149.

AM Vermeulen, P., Zietsma, C., Greenwood, R., \& Langley, A. (2016). Strategic responses to institutional complexity. Strategic Organization, 14(4), 277-286.

Argyris, C. \& Schön, D. (1974). Theory in Practice. San Francisco: Jossey-Bass.

Ashokan, M.S. (2015). Karmayogi: A biography of E. Sreedharan, Translated from the Malayalam by Rajesh Rajmohan, Gurgaon, India: Penguin.

Battilana, J., Leca, B. \& Boxenbaum, E. (2009). How actors change institutions: To wards a theory of institutional entrepreneurship, Academy of Management Annals, 3(1), 65-107.

Baunsgaard, V., and Clegg, S. R. (2013) 'Walls and Boxes': The Effects of Professional Identity, Power and Rationality on Strategies for Cross-Functional Integration, Organization Studies, 34(9) 1299-1325.

Boje, D.M. (2001). Narrative methods for organizational and communication research, Thousand Oaks, CA: Sage.

Brady, T. \& Davies, A. (2014). Managing structural and dynamic complexity: A tale of two projects, Project Management Journal, 45(4), 21-38.

Bresnan, M. \& Marshall, N. (2002). The engineering and evolution of cooperation? A tale of two partnering projects, International Journal of Project Management, 20, 497-505. 
Chi, C.S.F. \& Javernick-Will. (2011). Institutional effects on project arrangement: High-speed rail projects in China and Taiwan, Construction Management and Economics, 29(6), 595-611.

Chi, C.S.F., Chen, Y. \& Shi, W. (2014). Managing institutional change in international infrastructure projects, Engineering Project Organization Conference, Colorado, USA, July 29-31,

Chia, R., (2000). Discourse analysis organizational analysis. Organization, 7(3), 513-518.

Clegg, S. R. (1981) Organization and Control, Administrative Science Quarterly 26, 545-562.

Clegg, S.R. (1975). Power, rule and domination, London. Routledge.

Clegg, S.R., (1989). Frameworks of power. London, Sage.

Clegg, S.R., Pitsis, T.S., Rura-Polley, T. \& Marosszeky, M. (2002). Governmentality matters: designing an alliance culture of inter-organizational collaboration for managing projects, Organization Studies, 23(3), 317-337.

Cobley, P. \& Janz, L. (2004). Introducing semiotics, Royston, UK: Icon Books.

Czarniawska, B. (2004). Narratives in social science research, London: Sage.

Davies, A., Macaulay, S., DeBarro, T. \& Thurston, M. (2014). Making innovation happen in a megaproject: London's cross rail suburban railway system, Project Management Journal, 45(6), 25-37.

Dille, T. \& Söderlund, J. (2011) Managing inter-institutional projects: The significance of isochronism, timing norms and temporal misfits, International Journal of Project Management, 29, 480-490.

DiMaggio, P. (1988). Interest and agency in institutional theory, in Zucker, L. (Ed.) Institutional patterns and cultures, Cambridge, MA, Balinger, 3-22.

DiMaggio, P.J. \& Powell, W.W. (1983). The iron cage revisited: Institutional isomorphism and collective rationality in organizational fields, American Sociological Review, 48(2), 147-160. 
Drouin, N., Muller, R. \& Sankaran. S. (2013) frequently methods in project management research: Transformational and translational, Copenhagen: CBS Press.

Engwall, M. (2003). No project is an island: Linking projects to history and context, Research Policy, $32,789-808$.

Fan, G. H., \& Zietsma, C. (2016). Constructing a Shared Governance Logic: The Role of Emotions in Enabling Dually Embedded Agency. Academy of Management Journal, doi: 10.5465/amj.2015.0402.

Fincham, R., \& Forbes, T. M. (2016). Rhetoric, counter rhetoric and institutional complexity: Micropolitics in a mental health service. In Academy of Management Proceedings, January 2016, Doi:10.5465/AMBPP.2016.13261

Fligstein, N. (1997). Social skill and institutional theory. American Behavioural Scientist, 40(4), $397-$ 405 .

Fligstein, N., \& McAdam, D. (2011). Toward a general theory of strategic action fields. Sociological theory, 29(1), 1-26.

Flyvbjerg, B. (2012). Why mass media matter for planning research: The case of megaprojects, Journal of Planning Education and Research, 32(2), 169-181.

Flyvbjerg, B. (2014). What you should know about megaprojects and why?: An overview, Project Management Journal, 45(2), 6-19.

Flyvbjerg, B. (2017). Introduction: The iron law of megaproject management in B. Flyvbjerg. (Ed.). The Oxford handbook of megaproject management, Oxford: Oxford University Press, 1-20.

Flyvbjerg, B., Bruzelius, N. \& Rothengatter, W. (2003). Megaprojects and risk: An anatomy of ambition, Cambridge: Cambridge University Press. 
Friedland, R. \& Alford, R.R. (1991). Bringing society back in: Symbols, practices and institutional contradictions, In Powell, W.W. \& DiMaggio, P.J. (Eds.). The new institutionalism in organizational analysis, Chicago: University of Chicago Press, 232-263.

Gary, P.B. and Butler, S.D. (2010). The future of megaprojects, in Hatem, J. and Corkum, D. (Eds.) Megaprojects: Challenges and recommended practices, Washington, DC: American Council of Engineering Companies, 247-285.

Gellert, P.K. \& Lynch, B.D. (2003). Megaprojects as displacements, International Social Science Journal, 55(175) 15-25.

Giddens, A. (1984). The constitution of society, Cambridge: Polity.

Gil, N. \& Lundrigan, C. (2012). The leadership and governance of megaprojects, CIB Technical Report No. $3 / 2012$.

Grand, S., Rüegg-Stürm, J. and Arx, W. von (2010) Constructivist epistemologies in strategy as practice research in D. Golsorkhi, L. Rouleau, D. Seidl and E. Vaara (Eds), Cambridge. handbook of strategy as practice. Cambridge: Cambridge University Press, 63-78.

Greiman, V.A. (2013). Megaproject management: Lessons on risk and project management from the big dig, Hoboken: NJ: John Wiley.

Grün, O. (2004). Taming giant projects, Berlin: Springer-Verlag.

Hoffman, A.J. (2001). Linking organizational and field level analysis, Organization \& Environment, 14 (2), 133-156.

Javernick-Will, A. \& Scott, W.R. (2011). Who needs to know what? Institutional knowledge and global projects, in Scott, W.R., Levitt, R.E. \& Orr, R.J. (Ed.). Global projects: Institutional and political challenges, Cambridge, UK: Cambridge University Press, 247-276. 
Jia, G., Yang, F., Wang, G., Hong, B. \& You, R. (2011). A study of megaprojects from a perspective of social conflict theory, International Journal of Project Management, 29, 817-827.

Jepperson, R. L. (1991). Institutions, institutional effects, and institutionalism. The New Institutionalism in Organizational Analysis, London, Sage, 143-163.

Kraatz, M. S., \& Block, E. S. (2008). Organizational implications of institutional pluralism. The Sage handbook of organizational institutionalism, In Greenwood, R., Suddaby, R. \& Sahlin, K. (Eds.), 243-275.

Lawrence, T.B. \& Suddaby, R. (2013). Institutions and institutional work, in Clegg, S.R., Hardy, C., Lawrence, T.B. \& Nord, W.R. (Eds). The SAGE handbook of organization studies, London: Sage, 215254.

Lee, N. \& Hassard, J. (1999). Organization unbound: actor-network theory, research strategy and institutional flexibility, Organization, 6(3): 391-404.

Levitt, R.E. \& Scott, W.R. (2017). Institutional challenges and solutions for global megaprojects in B. Flyvbjerg. (Ed). The Oxford Handbook of Megaproject Management, Oxford: Oxford University Press, 96-117..

Löfgren, O. (2015). Catwalking a bridge: A longitudinal study of transnational megaproject and its ritual life, In Van Marrewijk. (Ed.). Inside megaprojects: Understanding cultural practices in project management, Copenhagen: CBS Press, 33-68.

Luhman, J.T. \& Cunliffe, A.L. (2013). Key concepts in organization theory, London: Sage.

Lundin, R.A., Arvidsson, N., Brady, T. Ekstedt, E., Midler, C. \& Sydow, J. (2011) Managing and working in the project society: Institutional challenges of temporary organizations, Cambridge, UK: Cambridge University Press. 
Mahalingam, A., \& Levitt, R. E. (2007a). Institutional theory as a framework for analyzing conflicts on global projects. Journal of construction engineering and management, 133 (7), 517-528.

Mahalingam, A., \& Levitt, R. E. (2007b). Safety issues on global projects. Journal of construction engineering and management, 133 (7), 506-516.

Mahalingam, A., Levitt, R.E. \& Scott, W.R. (2011). Rules versus results: Sources and resolution of institutional conflicts on Indian metro railway projects, in Scott, W.R., Levitt, R.E. \& Orr, R.J. (Eds.). Global projects: Institutional and political challenges, Cambridge UK, Cambridge University Press, $113-134$

Merrow, E.W. (2011). Industrial megaprojects: Concepts, strategies and practices for success, Hoboken, NJ, John Wiley.

Meyer, J. W., \& Rowan, B. (1977). Institutionalized organizations: Formal structure as myth and ceremony. American Journal of Sociology, 83(2), 340-363.

Miller, R. \& Hobbs, B. (2005). Governance regimes for large complex projects, Project Management Journal, 36(3), 24-50.

Miller, R. \& Lessard, D.R. (2000). The strategic management of large engineering projects, Cambridge, MA: MIT Press.

Morris, P. \& Hough, G. (1987). The anatomy of major projects, London, Majors Projects Association.

Morris, P.W.G. \& Geraldi, J. (2011). Managing the institutional context for projects, Project Management Journal, 42(6), 20-32.

Müller, R. (2016). Governance and governmentality for projects; Enablers, practices and consequences, London: Routledge. 
North, D. C. (1990). Institutions, institutional change and economic performance. Cambridge, Cambridge University Press.

Oliomogbe, G.O. \& Smith, N.J. (2012). Value in megaprojects, Organization, Technology \& Management in Construction, 4(3), 617-624.

Oliver, C. (1991). Strategic responses to institutional processes, Academy of Management Review, 16, (1), 145-179.

Orr, R.J. \& Scott, W.R. (2011). Institutional exceptions on global projects: A process model, in Scott, W.R., Levitt, R.E. \& Orr, R.J. (Eds.). Global projects: Institutional and political Challenges, Cambridge, UK: Cambridge University Press, 135-182.

Orr, R.J., Scott, W.R., Levitt, R.E., Artto, K. \& Kujala, J. (2011). Global projects: Distinguishing features, drivers and challenges in Scott, W.R., Levitt, R.E. \& Orr, R.J. (Eds.). Global projects: Institutional and political Challenges, Cambridge, UK: Cambridge University Press, 13-51.

Pickering, M. (2008). Introduction in Pickering, M. (Ed.) Research methods in cultural studies, Edinburgh: Edinburgh University Press.

Porsander, L. (2005). My name is Lifebuoy: An actor-network emerging from an action-net. In Czarniawska, B. \& Hernes, T. (Eds.) Actor-Network theory and organizing, Malmo, Liber \& CBS Press, $14-30$.

Powell, W.W. \& Colvyas, J.A. (2008). New institutionalism in Clegg, S.R. \& Bailey, J.R. (Eds.). International encyclopaedia of organization studies, (pp. 976-979), Thousand Oaks, CA: Sage, 976979.

Scott, W.R. (2004). Institutional theory: Contributing to a theoretical research program, (Revised 2004), in Smith, K.J. \& Hitt, M.A. (Eds.) Great minds in management: The process of theory development, Oxford: Oxford University Press, 460-484. 
Scott, W.R. (2008). Approaching adulthood: the maturing of institutional theory, Theory and Society, $37,(5), 427-442$.

Scott, W.R. (2011). The institutional environment of global projects in Scott, W.R., Levitt, R.E. \& Orr, R.J. (Eds.). Global projects: Institutional and political Challenges, Cambridge, UK: Cambridge University Press, 52-84.

Scott, W.R. (2014). Institutions and organizations: Ideas, interests and identities, 4th Edn. Los Angeles: Sage.

Scott, W.R., Levitt, R.E. \& Orr, R.J. (2008). Infrastructure construction projects in transnational contexts, SCANCOR 20th Anniversary Conference, Stanford University, Stanford, CA.

Scott, W.R., Levitt, R.E. \& Orr, R.J. (2011). Global projects: Institutional and political Challenges, Cambridge, UK: Cambridge University Press.

Seo, M. G., \& Creed, W. D. (2002). Institutional contradictions, praxis, and institutional change: A dialectical perspective. Academy of management review, 27(2), 222-247.

Smith, C. \& Winter, M. (2010), The craft of project shaping, International Journal of Managing Projects in Business, 3(1) 46-60.

Söderlund, J. (2004). Building theories of project management: past research, questions for the future, International Journal of Project Management, 22, 183-191.

Steinmo, S. (2008). Historical institutionalism in Donatella, D.P. \& Keating, M. (Eds.) Approaches and methodologies in social sciences: A pluralistic perspective, Cambridge, UK: Cambridge University Press, $118-138$.

Suddaby, R. (2010). Challenges of institutional theory, Journal of Management Inquiry, 19(1), 14-20. 
Sydow, J., Lindkvist, L. \& DeFillipi, R. (2004). Project-based organizations, embeddedness and repositories of knowledge: Editorial, Organization Studies, 25(9), 1475-1489.

ten Have, P. (2004). Understanding qualitative research and ethnomethodology, London: Sage.

Turner J.R. (1999). The handbook of project-based management. $2^{\text {nd }}$ edn. London: McGraw-Hill.

Turner J.R. (2004) The management large projects and programmes for web delivery. Aldershot: Gower.

Turner, J.R. (2006a). Towards a theory of project management: The nature of the project, International Journal of Project Management, 24(1), 1-3.

Turner, J.R. (2006b). Towards a theory of project management: The nature of the project governance and project management, International Journal of Project Management, 24(2), 93-95.

Turner, J.R. (2006c). Towards a theory of project management: The functions of project management, International Journal of Project Management, 24(3), 187-189.

Turner, J.R. (2006d). Towards a theory of project management: The nature of the functions of project management, International Journal of Project Management, 24(4), 277-279.

Turner, J.R. \& Müller (2003). On the nature of the project as a temporary organization, International Journal of Project Management, 21(1), 1-8.

Van Gestel, N., \& Hillebrand, B. (2011). Explaining stability and change: The rise and fall of logics in pluralistic fields. Organization Studies, 32(2), 231-252.

Van Marrewijk, A., Ybema, S., Smits, K., Clegg, S. \& Pitsis, T. (2016). Clash of the titans: Temporal organizing and collaborative dynamics in the Panama Canal megaproject, Organization Studies, 37(12), 1745-1769. 
Van Marrewijk. (Ed.) (2015). Inside megaprojects: Understanding cultural practices in project management, Copenhagen: CBS Press.

Weedon, C. (1987). Feminist practice and poststructuralist theory. Oxford: Basil Blackwell.

Weedon, C. (2006). Feminism and the principle of poststructuralism, in, J. Storey (Ed.) Cultural theory and popular culture: A reader, Essex: Pearson Education, 354-367.

Weick, K. E., \& Westley, F. (1999). Organizational Learning: Affirming an Oxymoron, in Clegg, S.R, Hardy, W, and Nord, W. R. (Eds) Managing and Organizations: Current Issues. London: Sage, 440458.

Williams, T \& Samset, K. (2010) Issues in front- end decision making on projects. Project Management Journal, 41(2), 38-49.

Wooten, M., \& Hoffman, A. J. (2016). Organizational Fields Past, Present and Future.

Zucker, L. G. (1977). The role of institutionalization in cultural persistence. American Sociological Review, 42(5), 726-743. 